\section{Containerized Strawberry Transplants Reduce Establishment-period Water Use and Enhance Early Growth and Flowering Compared with Bare-root Plants}

\author{
George Hochmuth ${ }^{1}$, Dan Cantliffe ${ }^{2}$, Craig Chandler $^{3}$, \\ Craig Stanley ${ }^{4}$, Eric Bish ${ }^{5}$, Eric Waldo ${ }^{5}$, Dan Legard ${ }^{6}$, \\ and John Duval ${ }^{7}$
}

ADDITIONAL INDEX wORDS. Fragaria $\times$ ananassa, irrigation, leaf area, plant establishment, plug transplants

\begin{abstract}
Summary. Experiments were conducted in two seasons in Dover, Fla. (central Florida), with bare-root and containerized (plug) strawberry (Fragaria $\times$ ananassa) transplants to evaluate transplant establishment-period water use, plant growth, and flowering responses in the 3 -week transplant establishment period. Strawberry plug plants were established with 290 gal/acre water applied only with the transplant at planting time, while 200,000 gal/acre from microjet or 1 million gal/acre of water from sprinkler irrigation were used to establish bare-root transplants. Root, shoot, and crown dry matter of plug plants rapidly increased during the establishment period, while there was a decline in leaf area and root and crown mass of bare-root plants, even with sprinkler or microjet irrigation. Water applied with the bare-root transplant only at planting was not enough to keep the plant alive during the establishment period. Large plug plants, but not irrigated bare-root plants, began flowering at 3 weeks after planting. Plug plants were used to successfully establish strawberry crops with low water inputs.
\end{abstract}

W ater is required for successful establishment, growth, and sometimes frost protection of strawberries in Florida (Albregts and Howard, 1982, 1984; Maynard et al., 2000). Strawberry crops are established with bare-root transplants (Fig. 1) in early fall, under high temperatures. Most of these transplants are produced in northern states or Canada under cool summer/fall climates and transplanted in Florida in September and October under high-temperature and high-evapotranspiration conditions (Albregts and Chandler, 1995). For example, for the period 1929-89, the

Florida Agricultural Experiment Station Journal Series No. R-10030.

${ }^{1}$ Professor, Horticultural Sciences Department and Center Director, North Florida Research and Education Center, University of Florida.

${ }^{2}$ Professor and Chairman, Horticultural Sciences Department, University of Florida. ${ }^{3}$ Professor, Horticultural Sciences Department, Gulf Coast Research and Education Center, University of Florida.

${ }^{4}$ Professor, Soil and Water Science Department, Gulf Coast Research and Education Center, University of Florida.

${ }^{5}$ Former graduate students, Horticultural Sciences Department, University of Florida.

${ }^{6}$ Former Assistant Professor, Department of Plant Pathology, Gulf Coast Research and Education Center, University of Florida. Currently California Strawberry Commission.

${ }^{7}$ Former Assistant Professor, Horticultural Sciences Department, Gulf Coast Research and Education Center, University of Florida. use permit from the water management district is required. Without overhead sprinkler water, these transplants would rapidly wilt, lose their leaves, and die. Sprinkler irrigation systems are used daily during the first 2 weeks after field planting to keep plants fresh and minimize leaf loss during establishment of the newly transplanted strawberry crop (Albregts and Howard, 1984, 1985a). The establishment phase can account for up to one-third of the total-season use of water on the strawberry crop; as much as 20 inches of water are used during plant establishment (Albregts and Howard, 1985a). Water use for this establishment phase can be reduced with intermittent sprinkling (Albregts and Howard, 1985a) or with microjet irrigation systems, which are more efficient than standard high-volume overhead sprinkler systems (Clark et al., 1992, 1993). Water applications can be reduced with more efficient irrigation systems, yet large amounts of water still are applied for plant establishment and the newer irrigation systems represent a considerable installation expense for the grower.

New planting technologies, such as containerized (plug) plants (Fig. 1), have been developed for strawberry production (Bish et al., 1997, 2001; Grout and Millam, 1985; Hochmuth et al., 1998; Poling, 1993a, 1993b; Poling and Maas, 2000; Poling and Parker, 1990). Plug transplants are in widespread use in the vegetable industry for tomato (Lycopersiconesculentum), pepper (Capsicum annuum), watermelon (Citrulluslanatus), eggplant (Solanum melongena), and other vegetables, and are now commercially available for strawberry producers in Florida. Plug transplants typically provide for quicker establishment with less water stress to

\begin{tabular}{llll}
\hline $\begin{array}{l}\text { Units } \\
\text { To convert } \\
\text { U.S. to SI, }\end{array}$ & & & \\
multiply by & U.S. unit & SI unit & $\begin{array}{l}\text { To convert } \\
\text { SI to U.S., } \\
\text { multiply by }\end{array}$ \\
\hline 0.4047 & acre(s) & $\mathrm{ha}$ & $2.471 \mathrm{l}$ \\
$\mathrm{l}$ & $\mathrm{cbar}$ & $\mathrm{kPa}$ & 1 \\
29.5735 & $\mathrm{fl} \mathrm{oz}$ & $\mathrm{mL}$ & 0.0338 \\
0.3048 & $\mathrm{ft}$ & $\mathrm{m}$ & 3.2808 \\
3.7854 & $\mathrm{gal}$ & $\mathrm{L}$ & 0.2642 \\
9.3540 & $\mathrm{gal} / \mathrm{acre}$ & $\mathrm{L} \cdot \mathrm{ha}^{-1}$ & 0.1069 \\
2.5400 & inch $(\mathrm{es})$ & $\mathrm{cm}$ & 0.3937 \\
25.4000 & inch $(\mathrm{es})$ & $\mathrm{mm}$ & 0.0394 \\
6.4516 & inch & $\mathrm{cm}$ & 0.1550 \\
1.1209 & $\mathrm{lb} / \mathrm{acre}$ & $\mathrm{kg} \cdot \mathrm{ha}^{-1}$ & 0.8922 \\
0.1198 & $\mathrm{lb} / \mathrm{gal}$ & $\mathrm{kg} \cdot \mathrm{L}^{-1}$ & 8.3454 \\
28,350 & $\mathrm{oz}$ & $\mathrm{mg}$ & $3.5274 \times 10^{-5}$ \\
6.8948 & $\mathrm{psi}$ & $\mathrm{kPa}$ & 0.1450 \\
$\left({ }^{\circ} \mathrm{F}-32\right) \div 1.8$ & ${ }^{\circ} \mathrm{F}$ & ${ }^{\circ} \mathrm{C}$ & $\left(1.8 \times{ }^{\circ} \mathrm{C}\right)+32$
\end{tabular}



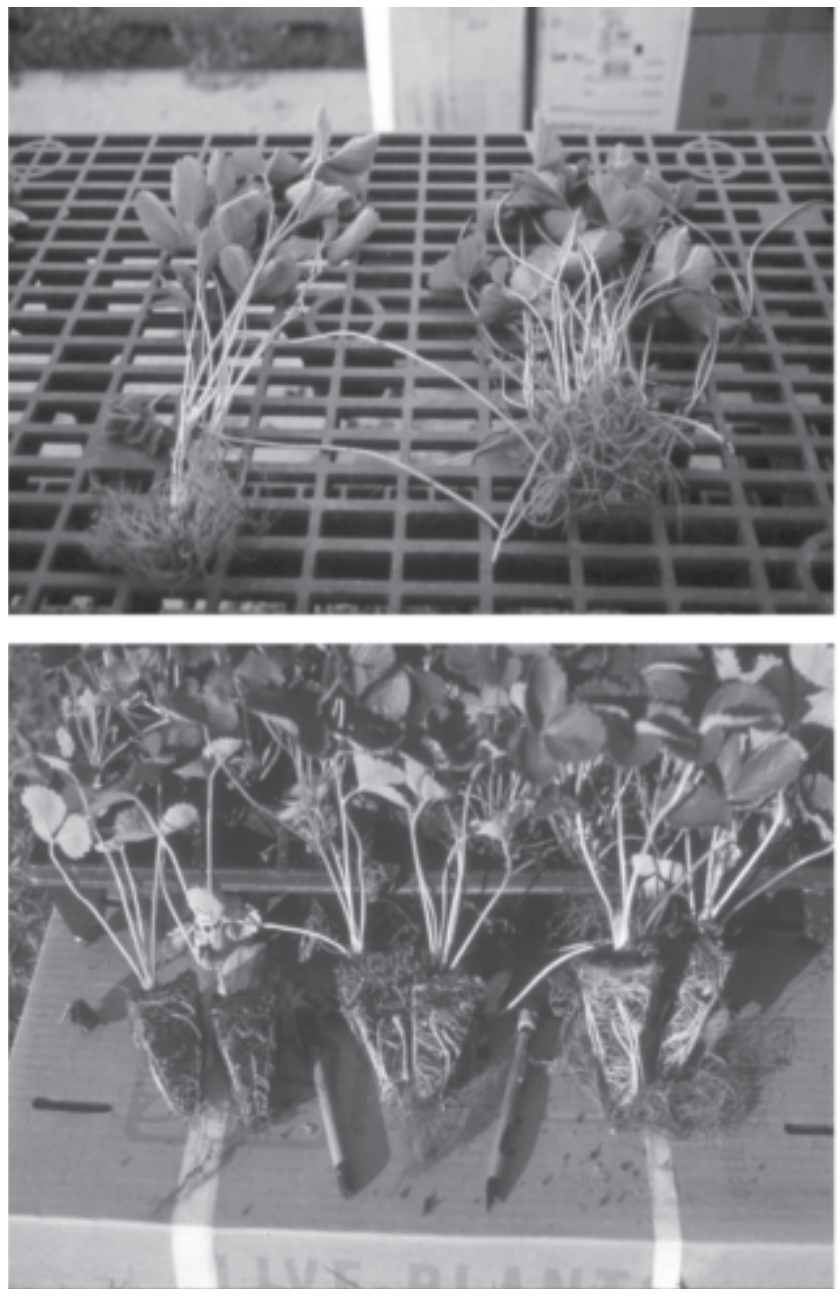

Fig. 1. Strawberry transplants ready to plant in the field in Dover, Fla. In top photo are bare-root transplants with small plants on left and large plants on right. The dimension of the "squares" under plants is $0.75 \times 1.5$ inches. In bottom photo are containerized "plug" transplants with small, medium, and large plugs from left to right. Pencil on right is 6 inches long $(1 \mathrm{inch}=2.54 \mathrm{~cm})$.

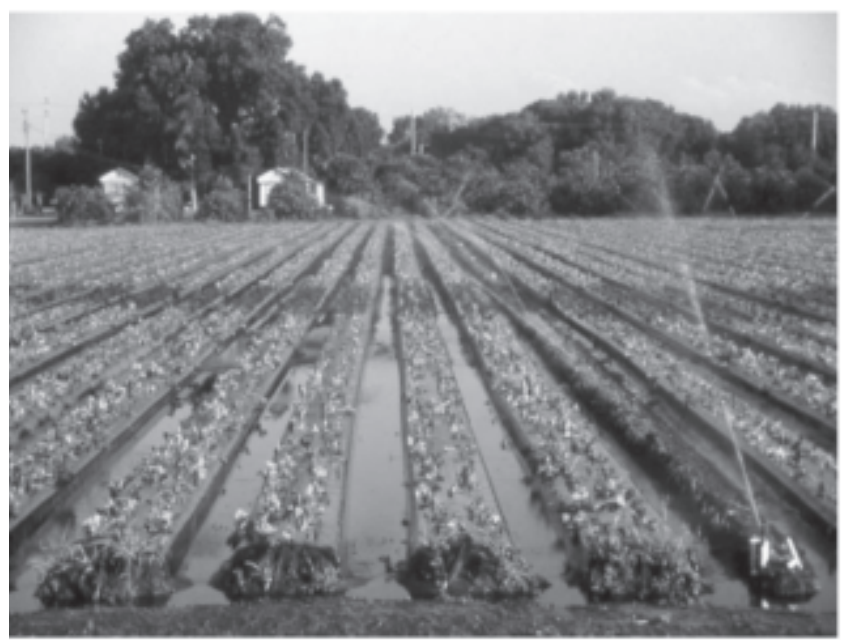

Fig. 2. Sprinkler irrigation used to establish fresh-dug bare-root strawberry transplants in Dover, Fla. the transplant. Containerized strawberry plants are grown from rooted runner tips in cell-trays in a greenhouse for several weeks. The plugs are transplanted in the fruit production field with the root system intact and the growing medium still attached to the roots (Bish et al., 2001). Researchers in several strawberry production areas (Bish et al., 2001; Poling and Maas, 2000 ) have shown that plug plants can be successfully used to establish crops, but details on plant establishment water use efficiency, optimum plug plant size, and impacts on early plant growth and flowering are lacking.

Currently, very little of the strawberry crop in Florida is established with plugs, but some growers use plug plants to replace missing or dead bare-root transplants during the first 2 weeks after transplanting. Growers do not directly pay for water used for production of strawberry in Florida, but competition with urbanization for water resources is increasing and will put pressure on water availability for farmers (Southwest Florida Water Management District, 2000). The main objective of the present research was to determine water requirements for establishing bare-root and plug plants for the annual-hill strawberry production system, such as that used in Florida and southeastern U.S. We also wanted to document early transplant growth and flowering responses for plug and bare-root strawberry transplants, since any new transplant system must maintain, or improve, the early plant growth typical of the current bare-root transplant system used in Florida.

\section{Materials and methods}

Research was conducted to evaluate the effects of irrigation method and transplant type and size on strawberry plant establishment and early growth and flowering during a 3 -week transplant establishment period. This research was conducted in the main Florida strawberry-producing region in central Florida at the University of Florida, GulfCoast Research and Education Center, in Dover in the 1997-98 and 1998-99 seasons. Strawberry crops were grown with standard strawberry production practices used in the central Florida production area (Albregts and Howard, 1984; Maynard et al., 2000). The soil used was Seffner fine sand (sandy, siliceous, hyperthermic 
Quartzipsammentic Haplumbrept). Cover crops of sorghum-sudan grass (Sorghum bicolor $\times$ S. arundinaceum) were incorporated into the soil by disking and plowing to prepare the soil for bed formation and preplant fertilization. A dry $9 \mathrm{~N}-0.9 \mathrm{P}-10 \mathrm{~K}$ fertilizer was broadcast at $500 \mathrm{lb} /$ acre and incorporated in the soil. Raised beds, 28 inches wide and 7 inches high, were prepared on 4 -ft centers. Drip irrigation tubing was placed on the surface in the center of the beds. The drip irrigation system consisted of tubes with emitters on 18 -inch spacing, delivering $0.37 \mathrm{gal} / \mathrm{h}$ at $10 \mathrm{psi}$ (Netafim, Altamonte Springs, Fla.). The drip irrigation system was used to apply water to keep the soil under the mulch from drying out during the establishment period and for routine crop irrigation after the establishment period. Amounts of drip-applied water were not included in calculations of amounts of water applied for plant establishment. Beds were covered with black polyethylene mulch. The soil was fumigated with methyl bromide/ chloropicrin (98\% methyl bromide/ $2 \%$ trichloronitromethane) mixture at $350 \mathrm{lb} /$ acre by injecting the mixture into the soil during bed formation and mulch application.

The study was a split-split-plot experiment, with three factors and four replications, conducted for 2 years. The first factor (main plot) consisted of three plant establishment irrigation treatments (used only during the transplant establishment period): overhead sprinkler, microjet, or no supplemental irrigation. Overhead sprinkler nozzle output was $90 \mathrm{gal} / \mathrm{h}(1.5 \mathrm{gal} / \mathrm{min})$ and sprinklers were arranged to provide $50 \%$ overlap of sprinkler pattern. The microjet system consisted of \#28 blue jets $\left(280^{\circ}\right.$; Netafim), spaced every $2.5 \mathrm{ft}$ with flow rate of $18 \mathrm{gal} / \mathrm{h}$ $(0.3 \mathrm{gal} / \mathrm{min})$. The microjet irrigation system was operated by a time clock in a continuously pressurized water delivery system, for $1 \mathrm{~min}$ on and 9 min off from 0900 to $1730 \mathrm{HR}$ during the first 2 weeks after planting. The no(supplemental) irrigation treatment consisted of hand application of 50 $\mathrm{mL}$ water with each transplant.

The second experimental factor (sub-plot) was the transplant propagation method, bare-root or plug transplants (Fig. 1). Both types of transplants ('Sweet Charlie') were grown at the same farm site in western North Carolina (We-Gro-Rite, Andrews, N.C.). Bare-root plants were mechanically dug from the field on 2 Oct. of both years and immediately transported to the research site in Florida. The plug transplants were grown in a passively ventilated greenhouse in plastic containerized trays with a cell size of $2 \times 2$ $\times 3$ inches deep. Bare-root transplants were kept in a cooler room at $40^{\circ} \mathrm{F}$ for $7 \mathrm{~d}$ until planted and the plugs were kept in an open-sided shade house until planted.
The third factor (sub-sub-plot) was the size of the transplant, based on the diameter of the crown of the plug transplant just above the containerized tray growing media surface or the soil line in the case of field-grown bare-root transplants. In both growing seasons, three sizes of plants (crown diameter) were evaluated: small $(6 \mathrm{~mm})$, medium $(8 \mathrm{~mm})$, and large $(10 \mathrm{~mm})$. Grading of plant size was done manually without measuring each crown but visually comparing each plant to standard plants of known crown diameters. To determine means and ranges of crown sizes for each grade, eight random transplants were selected. The plants were separated into roots (washed free of soil or media), leaves (blades with petioles), and plant crowns. Crown was the part of the plant remaining after the leaves and roots had been removed. Leaf area, leaf number, and crown diameter variables were measured. Plant parts were dried at $140{ }^{\circ} \mathrm{F}$ for $3 \mathrm{~d}$ or until a constant weight was recorded, and weighed. Data for the initial characteristics of the transplants used in this study are presented in Table 1. We chose the crown as the indicator of plant size because the crown is a major energy storage organ in a strawberry transplant and the crown would be an easy, practical plant organ for measuring in a plant-size grading operation on the plant farm. Other researchers chose plant height (leaf length) as the measure of strawberry plant size (Crawford et al., 2000).

Table 1. Initial characteristics of strawberry transplants [mean (sE)] used in 1997-98 and 1998-99 transplant establishment studies in Dover, Fla. (averages of eight-plant samples selected based on crown diameter).

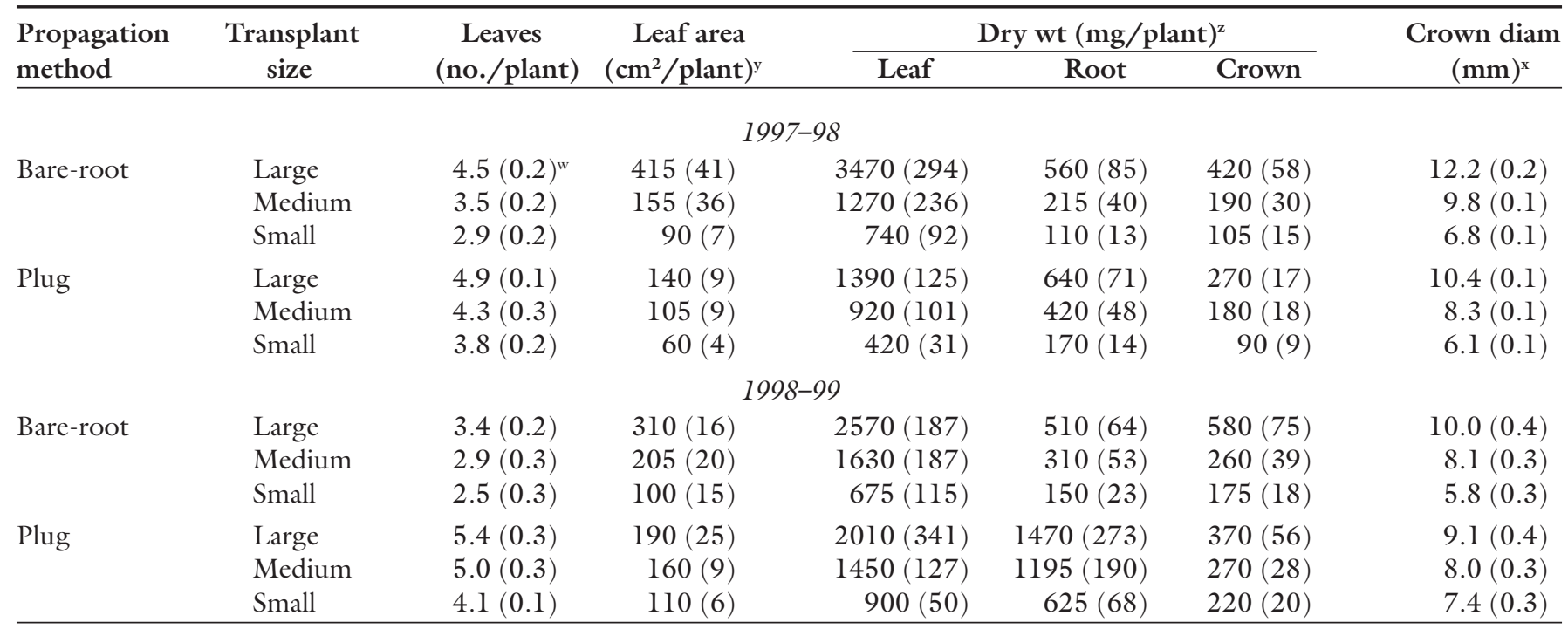

${ }^{2} 1.0 \mathrm{mg}=3.5274 \times 10^{-5} \mathrm{oz}$.

y $1.0 \mathrm{~cm}^{2}=0.1550$ inch $^{2}$.

${ }^{x} 1.0 \mathrm{~mm}=0.0394$ inch.

"SE in parentheses. 
Strawberry plug and bare-root plants were manually planted in the field in Dover, Fla., on 9 Oct. each year, with two rows of plants on each bed and 12 inches between rows and between plants in the rows $(21,800$ plants/acre). Experimental units (plots) consisted of a 20 - $\mathrm{ft}$ section of a single bed with 40 plants/plot.

All plants received $50 \mathrm{~mL}$ water poured in the transplant hole at planting. Immediately after transplanting, the microjet and sprinkler irrigation treatments for transplant establishment were begun and continued for 2 weeks. Irrigation treatments were applied from 0900 to $1730 \mathrm{HR}$ each day. All plants received irrigation from the drip system for $30 \mathrm{~min}$ every second day during the establishment period to maintain optimum soil moisture potential at -12 cbar under the mulch. Soil moisture potential was measured with a tensiometer with the ceramic tip 6 inches deep in the root zone. The amount of drip-applied water was uniform across plants with all plant establishment-period irrigation treatments and was not considered for plant establishment purposes.

Strawberry plants received $\mathrm{N}$ and $\mathrm{K}$ fertilizers through the drip irrigation system in the third week of the establishment period. The fertilizer was a liquid fertilizer $(4 \mathrm{~N}-0.9 \mathrm{P}-4.8 \mathrm{~K})$, formulated from urea-ammonium nitrate, potassium nitrate, potassium chloride, phosphoric acid, calcium nitrate, and magnesium nitrate. The fertilizer solution $($ specific weight $=10.0 \mathrm{lb} / \mathrm{gal}$ ) was applied at $10.5 \mathrm{gal} / \mathrm{acre}$. Diseases and insects were controlled by applications of recommended pesticides and biological control agents (Maynard et al., 2000).

Each season the amounts of water used in the plant establishment period were measured with water meters (Master Meter, Mansfield, Texas) placed in the irrigation submain serving each irrigation treatment main plot and were read daily. Measurements were made of plant development (leaf, crown, root dry weight, leaf area, crown diameter, and number of flowers) 3 weeks after planting. Single plants (using the second plant from the end of a row in a plot to avoid the "edge effect") were excavated from the field soil by digging with a spade in a 6-inch radius ( 8 inches deep) around each plant. Shoots and roots were washed free of soil and separated into leaves,

Table 2. Climatic information for the two production seasons (1997-98 and 1998-99) of strawberry research at Dover, Fla.

\begin{tabular}{|c|c|c|c|c|c|}
\hline Month & $\begin{array}{l}\text { Daily max } \\
\text { temp }\left({ }^{\circ} \mathrm{C}\right)^{\mathrm{z}}\end{array}$ & $\begin{array}{l}\text { Daily min } \\
\text { temp }\left({ }^{\circ} \mathrm{C}\right)\end{array}$ & $\begin{array}{l}\text { Daily avg } \\
\text { temp }\left({ }^{\circ} \mathrm{C}\right)\end{array}$ & $\begin{array}{c}\text { Rainfall } \\
(\mathrm{cm})^{\mathrm{y}}\end{array}$ & $\begin{array}{c}\text { Potential evapo- } \\
\text { transpiration } \\
(\mathrm{cm})^{\mathrm{y}}\end{array}$ \\
\hline \multicolumn{6}{|c|}{ 1997-98 } \\
\hline October & 28 & 17 & 23 & 11.5 & 4.6 \\
\hline November & 24 & 13 & 19 & 8.1 & 2.7 \\
\hline December & 21 & 12 & 17 & 37.7 & 1.9 \\
\hline January & 22 & 12 & 17 & 9.00 & 3.4 \\
\hline February & 22 & 11 & 17 & 21.4 & 6.7 \\
\hline March & 23 & 12 & 17 & 20.1 & 9.1 \\
\hline April & 27 & 16 & 22 & 0.08 & 9.3 \\
\hline Avg & 24 & 13 & 19 & & \\
\hline Sum & & & & 107.9 & 37.7 \\
\hline \multicolumn{6}{|c|}{ 1998-99 } \\
\hline October & 29 & 19 & 24 & 1.8 & 8.9 \\
\hline November & 27 & 16 & 22 & 4.5 & 7.4 \\
\hline December & 25 & 13 & 19 & 1.7 & 5.3 \\
\hline January & 24 & 11 & 17 & 4.1 & 7.0 \\
\hline February & 75 & 10 & 17 & 1.2 & 7.1 \\
\hline March & 26 & 9 & 17 & 1.8 & 9.9 \\
\hline Avg & 26 & 13 & 19 & & \\
\hline Sum & & & & 15.1 & 45.6 \\
\hline
\end{tabular}

plant crowns, and roots, then dried and weighed as previously described for the transplants.

Data were analyzed separately for each year by analysis of variance for a split-split-plot experiment in randomized complete-block design with four blocks. Main effects and interaction means, when significant, were compared with least significant difference values at $P \leq 0.05\left(\mathrm{LSD}_{0.05}\right)$ values (SAS Institute, 1993).

\section{Results}

Climatic Data. The weather data, including temperature, rainfall, and potential evapotranspiration(ET), collected during the course of the research are summarized in Table 2 . The climatic conditions of October, the month of planting, were similar both years to the mean maximum and minimum temperatures for the period 1929 to 1989 (Albregts et al., 1990). The first season of this study was slightly cooler, considerably wetter, and the ET was lower than that of the second season, but both seasons were conducive to normal strawberry production in central Florida. There were no disease or insect problems observed in either production season and there were no observed differences in disease or insect pressures between plants started from plug or bare-root transplants.

Table 3. Water use during establishment period with three irrigation methods during two seasons of strawberry transplant establishment research at Dover, Fla.

\begin{tabular}{|c|c|c|c|}
\hline Season & $\begin{array}{c}\text { Manual } \\
\text { watering } \\
\text { at planting }\end{array}$ & Microjet $^{z}$ & Sprinkler $^{\mathrm{z}}$ \\
\hline & \multicolumn{3}{|c|}{ - gal/acre $)^{y}$} \\
\hline 1997-98 & 290 & 277,000 & $1,094,500$ \\
\hline 1998-99 & 290 & 395,000 & $1,267,000$ \\
\hline
\end{tabular}


Table 4. Main effects of transplant size on strawberry early plant growth variables measured at 3 weeks after transplanting at Dover, Fla., over two seasons, 1997-98 and 1998-99.

\begin{tabular}{lcccc}
\hline & \multicolumn{4}{c}{ Plant growth variable } \\
\cline { 2 - 5 } $\begin{array}{l}\text { Transplant } \\
\text { size }\end{array}$ & $\begin{array}{c}\text { Leaves } \\
(\text { no. } / \text { plant })\end{array}$ & $\begin{array}{c}\text { Leaf area } \\
\left(\mathrm{cm}^{2} / \text { plant }\right)^{\mathrm{z}}\end{array}$ & $\begin{array}{c}\text { Leaf dry wt } \\
(\mathrm{mg} / \mathrm{plant})^{\mathrm{y}}\end{array}$ & $\begin{array}{c}\text { Plant crown } \\
\text { diam }(\mathrm{mm})^{\mathrm{x}}\end{array}$ \\
\hline
\end{tabular}

\begin{tabular}{|c|c|c|c|c|}
\hline \multicolumn{5}{|c|}{$1997-98$} \\
\hline Large & 3.6 & & & 8.6 \\
\hline Medium & 3.4 & & & 7.7 \\
\hline Small & 2.8 & & & 6.3 \\
\hline $\mathrm{LSD}_{0.05}{ }^{\mathrm{w}}$ & 0.3 & $\mathrm{~N} / \mathrm{A}^{\mathrm{v}}$ & $\mathrm{N} / \mathrm{A}$ & 0.4 \\
\hline \multicolumn{5}{|c|}{ 1998-99 } \\
\hline Large & 4.1 & 231 & 1903 & 9.8 \\
\hline Medium & 3.6 & 163 & 1356 & 8.3 \\
\hline Small & 3.0 & 112 & 770 & 7.1 \\
\hline $\mathrm{LSD}_{0.05}$ & 0.4 & 32 & 282 & 0.6 \\
\hline
\end{tabular}

WATER APPLication. Water applied for transplant establishment was least with the non-irrigated plug plants, which received water $(50 \mathrm{~mL} /$ plant) applied to the planting hole at transplanting (Table 3). Water use was intermediate with the microjet system and greatest with the sprinkler system. There was about 4000 times more water applied to establish the sprinkler-irrigated bare-root plants (present commercial method) compared with the non-irrigated plug plants.

LEAF NUMBER, AREA, AND DRY WEIGHT. Leaf numbers were measured for all plants to determine the degree of leaf loss for the transplant types under the irrigation treatments. Numbers of leaves on transplants at time of planting are presented in Table 1. Large transplants had more leaves than small plants and plugs had more leaves than bare-root plants at planting. Bare-root plants had more leaves in the first season than bare-root plants in the second season. Plug plants had more leaves in the second season than the first season. These differences between seasons probably are due to differences in environmental and cultural practices between seasons. Leaf number between seasons was more uniform for plug plants than for bareroot plants, probably because of more uniform seasonal growing conditions in the greenhouse than outdoors with bare-root plants.

Leaf number was affected by the main effects of plant size in both seasons. Mean leaf number 3 weeks after planting was greatest with large (3.6 leaves) or medium (3.4 leaves) transplants and least (2.8 leaves) with small transplants in the 1997-98 season (Table 4). In the second season, leaf number for large transplants was greatest with 4.1 leaves, intermediate with medium transplants ( 3.6 leaves), and least (3.0 leaves) with small transplants. The relative numbers of leaves for the three plant sizes were reflective of the numbers of leaves on the transplants at planting, greatest with large plants and least with small plants.

Irrigation method and propagation method interacted for effect on leaf number in both seasons (Table 5 ). In the 1997-98 season, plug plant leaf number was always greater than bare-

Table 5. Effects of the two-way interaction of irrigation method and plant propagation method on several plant growth variables measured at 3 weeks after transplanting at Dover, Fla. over two seasons, 1997-98 and 1998-99.

\begin{tabular}{|c|c|c|c|c|c|c|}
\hline \multirow{2}{*}{$\begin{array}{l}\text { Transplant } \\
\text { establishment } \\
\text { irrigation } \\
\text { treatment }\end{array}$} & \multirow[b]{2}{*}{$\begin{array}{c}\text { Propagation } \\
\text { method }\end{array}$} & \multicolumn{5}{|c|}{ Plant growth variable } \\
\hline & & $\begin{array}{c}\text { Leaves } \\
{\text { (no./plant })^{\mathrm{z}}}\end{array}$ & $\begin{array}{c}\text { Leaf area } \\
\left(\mathrm{cm}^{2} / \text { plant }\right)^{\mathrm{z}, \mathrm{y}}\end{array}$ & $\begin{array}{c}\text { Leaf } \\
\text { dry wt } \\
(\mathrm{mg} / \text { plant })^{\mathrm{z}, \mathrm{x}}\end{array}$ & $\begin{array}{l}\text { Crown } \\
\text { diam } \\
(\mathrm{mm})^{\mathrm{z}, \mathrm{w}}\end{array}$ & $\begin{array}{c}\text { Root } \\
\text { dry wt } \\
(\mathrm{mg} / \text { plant })^{z, x} \\
\end{array}$ \\
\hline \multicolumn{7}{|c|}{$1997-98$} \\
\hline \multirow[t]{2}{*}{ None } & Bare-root & 0.0 & 0.0 & 0.0 & 0.0 & 0 \\
\hline & Plug & 5.0 & 203 & 1529 & 9.0 & 591 \\
\hline \multirow[t]{2}{*}{ Microjet } & Bare-root & 2.6 & 94 & 596 & 9.5 & 329 \\
\hline & Plug & 4.9 & 165 & 1397 & 8.7 & 667 \\
\hline \multirow[t]{2}{*}{ Sprinkler } & Bare-root & 2.4 & 86 & 588 & 9.5 & 400 \\
\hline & Plug & 4.7 & 150 & 1281 & 8.5 & 648 \\
\hline \multicolumn{7}{|c|}{ 1998-99 } \\
\hline \multirow[t]{2}{*}{ None } & Bare-root & 1.6 & 55 & 343 & & \\
\hline & Plug & 4.8 & 270 & 2012 & $\mathrm{~N} / \mathrm{A}^{\mathrm{z}}$ & $\mathrm{N} / \mathrm{A}^{\mathrm{z}}$ \\
\hline \multirow[t]{2}{*}{ Microjet } & Bare-root & 2.7 & 151 & 1200 & & \\
\hline & Plug & 4.5 & 183 & 1533 & $\mathrm{~N} / \mathrm{A}^{\mathrm{z}}$ & $\mathrm{N} / \mathrm{A}^{\mathrm{z}}$ \\
\hline \multirow[t]{2}{*}{ Sprinkler } & Bare-root & 3.2 & 169 & 1368 & & \\
\hline & Plug & 4.7 & 185 & 1600 & $\mathrm{~N} / \mathrm{A}^{\mathrm{z}}$ & $\mathrm{N} / \mathrm{A}^{\mathrm{z}}$ \\
\hline
\end{tabular}


root plants, irrespective of irrigation method, but the degree of difference varied with irrigation method. Plug plants in 1997 had five leaves, irrespective of irrigation treatment. Bare-root transplants with no supplemental irrigation died. Irrigated plants supported only half the number of leaves compared with plug plants. There was a similar response measured in the 1998-99 season, although in the second season, some bare-root transplants survived with no irrigation. Using data in Tables 1 and 5 , plug plants, on average, maintained leaf number while bare-root plants lost leaves during the establishment period.

Transplant leaf area data at planting are presented in Table 1. Plug plants had more, but smaller leaves than bare-root plants, probably due to production system (greenhouse, containerized trays vs. open field). Strawberry leaf area was affected by the main effect of plant size in the second season. Leaf area was greatest with large plants, intermediate with medium-sized plants, and least with the small transplants (Table 4).

Irrigation method and propagation method interacted for effects on leaf area in both seasons (Table 5).
In the 1997-98 season, leaf area was greater with plug transplants than bareroot plants. The response was similar to that of leaf number in the first season (Table 4). These results showed that leaf area during plant establishment was better conserved with plug plants than with bare-root plants. The effect was greatest with no irrigation, compared to sprinkler and microjet irrigation. In the second season, with no irrigation, leaf area with plug plants was greater than with bare-root plants, but when irrigated, leaf area was similar between bare-root and plug plants (Table 5). In the second season (a dry season), wetting leaves with irrigation was required for bare-root plants to maintain leaf area similar to plug plants. In the first season (wetter), irrigation might have led to more leaf area loss due to foliar diseases under the wetter climatic conditions.

Leaf area was affected by the interaction of propagation method and plant size in the first season only (Table 6). With bare-root plants, leaf area was similar at 3 weeks after planting for large and medium transplants and for medium and small plants, but leaf area was greater with large plants than with small transplants. With plug transplants, leaf area was greatest with large transplants, intermediate with medium plants, and smallest with small plants.

Plug plants typically had less leaf dry matter than bare-root plants, except in the second season when small plug plants had more dry matter than small bare-root plants (Table 1 ).

Leaf dry weight in the second season was affected by the main effect of plant size. The responses of leaf dry weight were similar to those of leaf area, with greatest dry weight for large plants and least with small plants (Table 4).

The interaction of irrigation method and propagation method affected leaf dry weight in both seasons (Table 5). In the first season, leaf dry weight of plug plants was greater than leaf dry weight of bare-root plants irrespective of irrigation treatment. In the second season, leaf dry weight of plug plants with no irrigation or with microjet irrigation was greater than with bare-root plants. With sprinkler irrigation, leaf dry weights of bareroot and plug plants were similar. This response is similar to the responses for leaf area.

Leaf dry weight also was affected

Table 6. Effect of the interaction of propagation method and transplant size on several plant growth variables measured at 3 weeks after transplanting at Dover, Fla., over two seasons, 1997-98 and 1998-99.

\begin{tabular}{|c|c|c|c|c|c|c|}
\hline \multirow[b]{2}{*}{$\begin{array}{l}\text { Propagation } \\
\text { method }\end{array}$} & \multirow[b]{2}{*}{$\begin{array}{c}\text { Transplant } \\
\text { size }\end{array}$} & \multicolumn{5}{|c|}{ Plant growth variable } \\
\hline & & $\begin{array}{c}\text { Leaf area } \\
\left(\mathrm{cm}^{2} / \text { plant }\right)^{\mathrm{z}}\end{array}$ & $\begin{array}{c}\text { Leaf } \\
\text { dry wt } \\
(\mathrm{mg} / \text { plant })^{\mathrm{y}} \\
\end{array}$ & $\begin{array}{c}\text { Root } \\
\text { dry wt } \\
\text { (mg/plant)y }\end{array}$ & $\begin{array}{c}\text { Crown } \\
\text { dry wt } \\
(\mathrm{mg} / \text { plant })^{\mathrm{y}}\end{array}$ & $\begin{array}{c}\text { Flowers } \\
\text { (no./plant) }\end{array}$ \\
\hline & & & $1997-98$ & & & \\
\hline \multirow[t]{3}{*}{ Bare-root } & Large & 82 & 543 & 392 & & \\
\hline & Medium & 64 & 433 & 228 & & \\
\hline & Small & 35 & 209 & 110 & & \\
\hline \multirow[t]{3}{*}{ Plug } & Large & 234 & 2105 & 1071 & & \\
\hline & Medium & 171 & 1317 & 571 & & \\
\hline & Small & 112 & 785 & 264 & & \\
\hline \multicolumn{7}{|l|}{ Interaction } \\
\hline \multirow[t]{2}{*}{$\operatorname{LSD}_{0.05}{ }^{\mathrm{x}}$} & & 23 & 236 & 130 & $\mathrm{~N} / \mathrm{A}^{\mathrm{w}}$ & $\mathrm{N} / \mathrm{A}^{\mathrm{w}}$ \\
\hline & & & 1998-99 & & & \\
\hline \multirow[t]{3}{*}{ Bare-root } & Large & & & 863 & 569 & 0.0 \\
\hline & Medium & & & 417 & 251 & 0.0 \\
\hline & Small & & & 254 & 207 & 0.0 \\
\hline \multirow[t]{3}{*}{ Plug } & Large & & & 1803 & 447 & 1.5 \\
\hline & Medium & & & 1329 & 372 & 0.4 \\
\hline & Small & & & 586 & 198 & 0.1 \\
\hline \multicolumn{7}{|l|}{ Interaction } \\
\hline $\mathrm{LSD}_{0.05}$ & & $\mathrm{~N} / \mathrm{A}^{\mathrm{v}}$ & $\mathrm{N} / \mathrm{A}^{\mathrm{v}}$ & 298 & 105 & 0.6 \\
\hline $\begin{array}{l}{ }^{2} 1.0 \mathrm{~cm}^{2}=0.1550 \\
{ }^{2} 1.0 \mathrm{mg}=3.5274 \\
{ }^{\circ} \text { Least significant } \\
\text { "Three-way intera } \\
\text { "Interaction nonsi }\end{array}$ & $\begin{array}{l}\mathrm{P} \\
\mathrm{nt} \text {; results } \mathrm{p}\end{array}$ & n Table 7. & & & & \\
\hline
\end{tabular}


by the interaction of propagation method and plant size in the first season only (Table 6 ). With bare-root plants, leaf dry weight was greater for large plants than for small plants. Dry weight was similar for large and medium plants and for medium and small plants.

Crown Diameter AND DRY WEIGHT. Average transplant crown diameter data at planting are presented in Table 1 . In each season at planting, measured crown diameters were close to the desired selected grade sizes. There were minor differences in measured crown diameters compared to the chosen values.

Crown diameter was affected by propagation method in the second season, but not in the first season. Crown diameter was greater with plug plants $(8.7 \mathrm{~mm})$ than with bare-root plants $(8.0 \mathrm{~mm})$. This result showed that plug plants started growing during the establishment period because the crowns increased in diameter but crowns of bare-root plants did not. Crown diameter was influenced by the main effect of plant size. Crown diameter was greatest with large plants, intermediate with medium plants, and least with small plants in both seasons (Table 4). Crown diameter in the 1997-98 season was affected by the interaction of irrigation method and propagation method (Table 5 ). With no irrigation, crown diameter was greater with plug plants than bareroot plants because bare-root plants died by the third week after planting. With microjet and sprinkler irrigation, crown diameter with bare-root plants was greater than plug plants.

Transplant crown dry weight data at planting are presented in Table 1 .
Most often, crowns of similar diameter at 3 weeks after planting had similar dry weights. Dry weight of the plant crown was affected by irrigation method in the second season. Average crown dry weight was greatest with microjet irrigation $(402 \mathrm{mg})$, intermediate with sprinkler irrigation $(335 \mathrm{mg})$, and least with no irrigation $(284 \mathrm{mg})$. Crown dry weight was affected by the interaction of propagation method and plant size in the 1998-99 season. With bare-root plants, crown dry weight was greatest with large transplants and least with medium or small plants (Table 6). With plug plants, crown dry weight was greatest with large plants, intermediate with medium plants, and least with small transplants. In the first season, crown dry weight was affected by the interaction of irrigation method, propagation method, and plant size (Table 7). With no irrigation, bareroot plants died by the third week after planting, but plug plants continued to grow. Large bare-root plants had larger crown dry weight than large plug plants with microjet or sprinkler irrigation. Medium bare-root plant crowns grown with microjet irrigation were similar in weight to medium plug crowns, but with sprinkler irrigation, medium bare-root crowns were greater in weight than medium plug crowns. Small bare-root crowns were larger than small plug crowns with microjet irrigation, but with sprinkler irrigation, dry weight of small bare-root and plug crowns were similar.

ROOT DRY WEIGHT. Data for root dry weight at planting are presented in Table 1. Plug plants had more dry matter than bare-root plants in both seasons. Root dry matter of each bareroot plant size was similar in both sea- sons, while large, medium, and small plug plants in the second season had more dry matter than the respective sizes in the first season.

The main effect of irrigation influenced root dry weight of strawberry plants in the 1998-99 season. Root dry weight was greatest with either microjet (948 $\mathrm{mg}$ ) or sprinkler irrigation (988 $\mathrm{mg}$ ), and least for plants with no irrigation $(689 \mathrm{mg})$. Root dry weight was affected by the interaction of irrigation method and propagation method in the 1997-98 season. With no supplemental irrigation, root dry weight was greater with plug plants than bare-root plants, which died soon after planting (Table 5). With microjet or sprinkler irrigation, root dry weight was greater with plug plants than bare-root plants, but the difference was not as great as with no supplemental irrigation. Root dry weight also was affected by the interaction of propagation method and plant size in both seasons (Table 6 ). In the first season, with bare-root plants, root dry weight was greatest with large transplants. Root dry weight of medium and small plants was similar and less than with large bare-root plants. Root dry weight was greatest with large plug plants, intermediate with medium plug plants, and smallest with small plug plants. In the second season, root dry weight of bare-root plants was greatest for large transplants. Root dry weight of medium and small transplants was similar and both were less than large plants. Root dry weight of plug plants was greatest with large plants, intermediate with medium plants, and least with small plants.

Number OF Flowers. Number of flowers was affected by the interaction of propagation system and plant size

Table 7. Effect of the three-way interaction on number of flowers and strawberry crown dry weight measured at 3 weeks after planting at Dover, Fla., in 1997-98.

\begin{tabular}{|c|c|c|c|c|c|c|c|}
\hline \multirow{3}{*}{$\begin{array}{l}\text { Transplant } \\
\text { establishment } \\
\text { irrigation } \\
\text { treatment }\end{array}$} & \multirow[b]{3}{*}{$\begin{array}{c}\text { Propagation } \\
\text { method }\end{array}$} & \multicolumn{6}{|c|}{ Transplant size } \\
\hline & & \multicolumn{2}{|c|}{ Large } & \multicolumn{2}{|c|}{ Medium } & \multicolumn{2}{|c|}{ Small } \\
\hline & & $\begin{array}{c}\text { Flowers } \\
\text { (no./plant) }\end{array}$ & $\begin{array}{c}\text { Crown } \\
\text { dry wt } \\
(\mathrm{mg} / \text { plant })^{\mathrm{z}}\end{array}$ & $\begin{array}{c}\text { Flowers } \\
\text { (no./plant) }\end{array}$ & $\begin{array}{c}\text { Crown } \\
\text { dry wt } \\
(\mathrm{mg} / \text { plant })^{\mathrm{z}}\end{array}$ & $\begin{array}{c}\text { Flowers } \\
\text { (no./plant) }\end{array}$ & $\begin{array}{c}\text { Crown } \\
\text { dry wt } \\
(\mathrm{mg} / \text { plant })^{\mathrm{z}}\end{array}$ \\
\hline \multirow[t]{2}{*}{ None } & Bare-root & $0.0^{y}$ & $0.0^{\mathrm{y}}$ & 0.0 & 0.0 & 0.0 & 0.0 \\
\hline & Plug & 1.0 & 394 & 0.0 & 206 & 0.0 & 170 \\
\hline \multirow[t]{2}{*}{ Sprinkler } & Bare-root & 0.0 & 547 & 0.0 & 342 & 0.0 & 142 \\
\hline & Plug & 0.3 & 380 & 0.0 & 263 & 0.0 & 154 \\
\hline
\end{tabular}

${ }^{2} 1.0 \mathrm{mg}=3.5274 \times 10^{-5} \mathrm{oz}$

ynteraction least significant difference at $P \leq 0.05$ is 0.1 for comparisons of any two means for number of flowers and is 41 for comparisons of any two means for crown dry weight. 
in the second season. There were no flowers at the end of the establishment period on bare-root plants. Plug plants had flowers 3 weeks after transplanting, but there were more flowers on the large plug plants compared with either medium or small plants (Table 6). In the 1997-98 season, number of flowers was affected by the interaction of irrigation method, propagation method, and plant size (Table 7). Bare-root plants had no flowers 3 weeks after planting, irrespective of irrigation method or plant size. Only plug plants had flowers and there were more flowers with large plug plants than with medium or small plants.

\section{Discussion}

In these studies, plug plants were successfully used to establish strawberry crops with very low volumes of water during the establishment phase. The only establishment water plug plants received was a small volume, $50 \mathrm{~mL}$, applied to each plant at transplanting. Strawberry production in Florida is largely based in the rapidly urbanizing Orlando-Tampa corridor where competition for water availability for agriculture and urban use continues to increase (Southwest Florida Water Management District, 2000). The use of plug plants with watering the plants only at transplanting could save large amounts of transplanting water, up to 6 billion gal annually, for the 6000 -acre strawberry industry in central Florida. Currently, strawberry growers are not charged for water drawn from wells, but this will change as demand for water increases in this rapidly urbanizing area of Florida.

Use of plug plants not only saved water, but also led to more rapid establishment of transplants in the field. Maintaining healthy transplants with optimal number of leaves is important for successful strawberry plant establishment (Albregts and Howard, 1984, 1985a). A minimum of four living leaves for most strawberry cultivars was needed for best plant establishment and fruit yield in Florida strawberry crops established from bare-root plants (Albregts and Howard, 1985b). With plug transplants, the leaf number was greater than four leaves/plant at the end of the establishment period, irrespective of irrigation system in two seasons of research. Plug plants with no irrigation maintained all the leaves that were present at transplanting in both seasons. Even with irrigation, bare-root transplants lost 20\% to $25 \%$ leaves during the establishment stage. Leaf number also has been shown to be correlated with total fruit yield (Albregts and Howard, 1972, 1985a; Albregts et al., 1992) and minimizing leaf loss is important for maintaining early fruit yield (Albregts and Howard, 1985b).

Maintaining leaf area was important for maintaining a positive carbon balance needed for rapid growth in the early plant establishment period (Grout and Millam, 1985). Leaf area and leaf dry weight were best conserved during the plant establishment phase with plug plants. Leaf area of bare-root plants declined during the establishment period, even with sprinkler irrigation. Large amounts of water applied by sprinkler irrigation might increase the spread of foliar diseases in the field; therefore, plug plants might offer a reduced risk for disease spread. Further, plug plants might also be helpful for reducing disease in the fruiting field because many diseases can be propagated in the bare-root transplant nursery (Maas, 2000).

The size of the plant crown was associated with plant establishment success with plug plants. Crown diameter and size of plug plants increased during the establishment period whereas bare-root crown size did not. Root size and dry matter were important factors in lettuce transplant quality and for establishment in the field (Soundy et al., 2001a). Strawberry root dry weight rapidly increased with plug plants after planting in both seasons, whereas bare-root plants maintained or slightly lost root dry weight after planting. Although root size at transplanting for the three size categories of plug plants differed between seasons (greater in 1998-99), growth of plug roots was rapid in both seasons. These differences in initial root size might be related to transplant production practices in the greenhouse. For example, greenhouse fertilization practices had an impact on growth and yield of lettuce (Lactuca sativa) in the field (Soundy et al., 200la, 200lb).

Our results in Florida are different from studies in North Carolina. In one North Carolina study with bare-root plants, growth of three cultivars increased rapidly in the first month after planting (Fernandez et al., 2001). In our Florida studies, bare-root transplant growth was slow and the plants did not flower during the establishment period. In another North Carolina study, transplant growth and fruiting in most months were not affected by type of plant, plug or bare-root (Butler et al., 2002). In the latter North Carolina study, plant leaf area declined from October to November in bare-root plants but not plug plants, a similar response to our study. In our Florida studies, large plug plants led to flowering during the establishment period in both seasons, but even small plugs flowered in the second season. The different results between the North Carolina studies and ours might be due to warmer field conditions in Florida at planting time. Furthermore, a different strawberry cultivar, 'Chandler', was used in the North Carolina study. In neither season in Florida were there any flowers present at 3 weeks after planting with bare-root plants. Root dry weight was consistently greater for plug plants than bare-root plants in both seasons. Calculations from Table 1 show that shoot (leaf + crown dry weight) to root ratios for bare-root plants and for plug plants were similar across seasons. The relatively larger plug plants in the second season compared to the first might have played a role in the increased flowering in the second season. Large plug plants led to earlier flowering each season compared to medium or small plugs. More research is needed to better define the relative importance of transplant organ size on early flowering.

\section{Conclusions and practical applications}

The main findings of this research were:

1. Considerably less water was used to establish plug strawberry plants than bare-root plants. An amount of 50 $\mathrm{mL}$ water applied with the transplant at planting was sufficient for plug plant establishment. Using plug transplants could result in large savings (1 million gal/acre) in water used for the establishment of the strawberry crop in Florida.

2. Plug plants grew more rapidly than bare-root plants during the establishment period. Plug plants experienced little leaf loss during establishment and early root growth was greater than with bare-root plants.

3 . Flowering occurred during the 
plant establishment period on plug plants but not on bare-root plants. Flowering was earliest with large (10 $\mathrm{mm}$ ) plug transplants.

\section{Literature cited}

Albregts, E.E. and C.K. Chandler. 1995. Effect of transplant source on strawberry fruit production in Florida. Soil Crop Sci. Soc. Fla. Proc. 54:80-83.

Albregts, E.E. and C.M. Howard. 1972. Influence of defoliation at transplanting on strawberry growth and fruiting response. HortScience 7:569-570.

Albregts, E.E. and C.M. Howard. 1982. Effect of plant stress on strawberry performance. HortScience 17:651-652.

Albregts, E.E. and C.M. Howard. 1984. Strawberry production in Florida. Fla. Agr. Exp. Sta. Bul. 841. Univ. of Florida, Gainesville.

Albregts, E.E. and C.M. Howard. 1985a. Effect of intermittent sprinkler irrigation on establishment of strawberry transplants. Soil Crop Sci. Soc. Fla. Proc. 44:197-199.

Albregts, E.E. and C.M. Howard. 1985b. Correlation of leaf number at transplanting to strawberry fruit yield. HortScience 20:415-416.

Albregts, E.E., C.M. Howard, and C.K. Chandler. 1990. 1990 Climatological report and historical information from 1929-1990. Univ. Fla. Agr. Res. Educ. Ctr. Misc. Rpt. Dover AREC Res. Rpt. DOV 1990-1.

Albregts, E.E., C.M. Howard, and C.K. Chandler. 1992. Defoliation of strawberry transplants for fruit production in Florida. HortScience 27:889-891.

Bish, E.B., D.J. Cantliffe, and C.K. Chandler. 2001. A system for producing large quantities of greenhouse-grown strawberry plantlets for plug production. HortTechnology 11:636-638.
Bish, E.B., D.J. Cantliffe, G.J. Hochmuth and C.K. Chandler. 1997. Development of containerized strawberry transplants for Florida's winter production system. Acta Hort. 439:461-468.

Butler, L.M., G.E. Fernandez, and F.J. Louws. 2002. Strawberry plant growth parameters and yield among transplants of different types and from different geographic sources, grown in a plasticulture system. Hort Technology 12:100-103.

Clark, G.A., C.D. Stanley, E.E. Albregts, A.G. Smajstrla, and F.S. Zazueta. 1992. Water requirements and crop coefficients for strawberry production in S.W. Florida. Final Report to the Southwest Florida Water Management District, Brooksville, Fla.

Clark, G.A., C.D. Stanley. E.E. Albregts, and C.K. Chandler. 1993. Methods for reducing irrigation pumpage during establishment of fruiting strawberries. Final Report to the Southwest Florida Water Management District, Brooksville, Fla.

Crawford, T.D., D.G. Himmelrick, J.L. Sibley, and J.A. Pitts. 2000. Effect of runner plantlet size on performance of strawberry plug plants. Small Fruits Rev. 1:15-21.

Grout, B.W.W. and S. Millam. 1985. Photosynthetic development of micropropagated strawberry plantlets following transplanting. Ann. Bot. 55:129-131.

Fernandez, G.E., L.M. Butler, and F.J. Louws. 2001. Strawberry growth and development in an annual plasticulture system. HortScience 36:1219-1223.

Hochmuth, R., L. Leon, T. Crocker, D. Dinkins, and G. Hochmuth. 1998. Comparison of bare-root and plug strawberry plants in soilless culture in northern Florida. Fla. Coop. Ext. Serv. Rpt. SVREC 98-4, Univ. Florida, Gainesville.

Maas, J.L. 2000. Opportunities to reduce the potential for disease infection and spread with strawberry plug plants. Acta Hort. 513:409-414.
Maynard, D.N., G.J. Hochmuth, C.S. Vavrina, W.M. Stall, T.A. Kucharek, J.F. Price, T.G. Taylor, S.A. Smith, and A.G. Smajstrla. 2000. Strawberry production in Florida, p. 215-220. In: D.N. Maynard and S.M. Olson (eds.). Vegetable production guide for Florida. Fla. Coop. Ext. Serv. Circ. SP-170. Univ. Florida, Gainesville.

Poling, E.B. 1993a. Strawberry plasticulture in North Carolina: I. Developing a competitive horticultural industry requires "experts," not "participatory groups." HortTechnology 3:400-402.

Poling, E.B. 1993b. Strawberry plasticulture in North Carolina: II. Preplant, planting, and postplant considerations for growing 'Chandler' strawberry on black plastic mulch. HortTechnology 3:383-393

Poling, E.B. and J.L. Maas. 2000. Strawberry plug transplant technology. Acta Hort. 513:393-401.

Poling, E.B. and K. Parker. 1990. Plug production of strawberry transplants. Adv. Strawberry Prod. 9:37-39.

SAS Institute. 1993. SAS/STAT user's guide, Release 6.03 edition. SAS Inst., Cary, N.C.

Soundy, P., D.J. Cantliffe, G.J. Hochmuth, and P.J. Stoffella. 2001a. Nutrient requirements for lettuce transplants using a floatation irrigation system. I. Phosphorus. HortScience 36:1066-1070.

Soundy, P., D.J. Cantliffe, G.J. Hochmuth, and P.J. Stoffella. 2001b. Nutrient requirements for lettuce transplants using a floatation irrigation system. II. Potassium. HortScience 36:1071-1074.

Southwest Florida Water Management District. 2000. District water management plan, July 2000. 10 Sept. 2005. <http:// www.swfwmd.state.fl.us/about/documents/water_management_plan.pdf>. 